\title{
Acculturation of Brazilian NFL Fans in Virtual Interactions
}

\section{Aculturação de Fãs Brasileiros da NFL em Interações Virtuais}

\author{
André Luiz Maranhão de Souza-Leão \\ Universidade Federal de Pernambuco - UFPB - Brasil \\ desouzaleao.pq@gmail.com \\ ORCID: 0000-0002-7660-5845. \\ Bruno Melo Moura \\ Universidade Federal de Pernambuco - UFPB - Brasil \\ brunomtop@gmail.com \\ ORCID: 0000-0002-8205-4576.
}

Submetido em 28/04/2020; Aprovado em 29/05/2020.

\begin{abstract}
Purpose: NFL is one of the most representative phenomena of contemporary American culture, working as a means to acculturing other audiences to the U.S. environment. Brazil has the second biggest international audience of the league in the world, and part of it is engaged to social networks during game broadcasts. Methodology: The study adopts the netnographic approach as research method, which was based on monitoring Twitter hashtags launched by ESPN channels in Brazil during three seasons, between 2016 and 2019. Results: Our findings reveal three practices of acculturation: comparison between Brazilian and American features, the embodiment of American rituals and routine changes to adjust to the schedule of the league. Theoretical contributions: This research contributes to marketing literature by showing how fan's interaction on social networks about massively mediated entertainment objects (i.e., media sports) can incorporate and resonate in an acculturation process. Practical contributions: Marketing professionals can look at fannish (i.e., prosumerist) interactions to achieve opportunities and competitive advantages based on reliable information acquired on social networks.

Keywords: NFL; acculturation; fans; prosumption; netnography.
\end{abstract}

\section{Resumo}

Objetivo: A NFL é um dos fenômenos mais representativos da cultura americana contemporânea, funcionando como um meio de agregar outras audiências a ambiência dos EUA. O Brasil tem o segundo maior público internacional da liga no mundo, e parte dele se engaja nas redes sociais durante as transmissões de jogos. Metodologia: 0 estudo adota a abordagem netnográfica como método de pesquisa, baseado no monitoramento de hashtags do Twitter lançadas pelos canais da ESPN no Brasil durante três temporadas, entre 2016 e 2019. Resultados: Nossas descobertas revelam três práticas de aculturação: comparação entre características brasileiras e americanas, a personificação de rituais americanos e mudanças de rotina para se ajustar ao cronograma da liga. Contribuições teóricas: A presente pesquisa contribui para a literatura de marketing, mostrando como a interação dos fãs nas redes sociais sobre objetos de entretenimento massivamente mediados (i.e., esportes midiáticos) pode incorporar e ressonar em um processo de aculturação. Contribuições práticas: os profissionais de marketing podem observar as interações fânicas (i.e., prossumeristas) para obter oportunidades e vantagens competitivas embasadas por informações confiáveis adquiridas em redes sociais.

Palavras-chave: NFL; aculturação; fãs; prossumo; netnografia.

\section{Introduction}

Sports represent important aspects of the cultures that give origin to them. Many studies show how individuals who have recently arrived to a country, such as immigrants, pilgrims, refugees, use these aspects to adjust themselves to the new cultural contexts they are facing (Allen et al., 2010; Ha et al.,2014; Sawrikar \& Muir, 2010), since sports have the ability to express cultures and to participate in the cultural change dynamics (Whannel, 2014; Wenner, 2012). 
Whannel (2014) categorizes two types of sports modalities: media sports, whose commotion results from their broadcast and widespread in the media; and participation sports, which are legitimated when a big fraction of society practices them. Clearly, it not a matter of whether the sports belong to one or other modality; its association is dynamic and mutual. The practice of a sports modality can be made feasible, consolidated and become popular through its broadcasting.

Media sports tend to acquire global prominence due to the repercussion their broadcast tend to reach, which are capable of reaching and surpassing cultural barriers. However, although some sports are broadcast in many countries, they do not become global, because their transmissions remain local (Wenner, 2012; Whannel, 2014), such as the case of American football. Although American football has been growing throughout the years due to its world broadcast - which is led by NFL -, its practice in other countries does not surpass the United States (U.S.) and its rules remain unknown for most individuals (Oates \& Furness, 2014; Wenner, 2012).

Oates and Furness (2014) states that NFL is one of the greatest cultural phenomena of the contemporary American Way of Life. The country has its routine changed throughout the football season, between September and February. People living in the country (U.S.) have the tradition to stop in order to watch NFL games, mainly the Sunday games either in the stadiums (always crowded) or on the TV families usually watch up to three games a day (Axelrod, 2001; Wenner, 2012). The strong relationship the country has with its main sports league results from its ability to represent and guide social, ethical, patriotic and capitalist practices, either through athletic confrontations among teams or through advertisement and brands linked to game broadcasts (Wenner, 2014).

The way to enjoy the greatest American sports modality has been changed by the manner NFL conducts the expansion of this modality: for approximately two decades the priority has been given to viewers who watch the games on TV, rather than to the ones who go to the stadiums (Wenner, 2008). This action is linked to the market view of the league, which became more profitable worldwide (Ozanian, 2017), kept its expansion and sought consolidation in different world markets (ESPN, 2018; Willis, 2020).

Nowadays, Brazil has the second largest NFL audience outside the United States, which reached approximately 23 million viewers during the last championship game: Super Bowl LIV in 2020 February (Ohata, 2020; Rogenski, 2020). The country is only behind Mexico, which is a neighbor country to the U.S. and seat of league games since 2005. Besides watching the games on TV, part of Brazilian NFL viewers engage in social networks during game broadcasts to widespread the modality. This consumption practice is featured as an active reception of media texts (Guschwan, 2012; Jenkins, 2008) by fans who engage in a participatory culture by making the option for being part of the process to give meaning and outspread the content they consume (de Souza-Leão \& Moura, 2018; Jenkins, 2014).

Fans resemble what Ritzer (2014) defines as prosumption by freely and spontaneously outspreading the consumed media content: productive consumers who engage in pro-active and dynamic acts by sharing their viewpoints with other consumers, by changing the reach, repercussion and even the quality of what they consume. This community interaction happens in consumption choices and in groups of consumers set to share impressions about brands, services and activities (Arnould \& Thompson, 2005; McAlexander et al., 2002). Such consumption practices can express social identities, but, mainly establish an intimate relationship between consumers and the culture they exalt (Belk et al., 2013), which is formalized by the large number of resources available to legitimize practices through it (Allen et al., 2010). American football is, therefore, a cultural product of the U.S. that has the power to disseminate the country's ideology and culture to other nations (Nye Jr., 2015).

Nowadays, cultural identification is no longer limited by territory, ethnicity or traditions; it is expressed through the negotiation exercised by social subjects, who combine one or more cultures they have contact with (Berry, 2005; Luedicke, 2011). Based on a broader sense, globalization allowed cultures - that in the past did not reach certain individuals - to have more influence on the cultural identification process, which leads to an acculturation process (Berry, 1980; Sawrikar \& Muir, 2010). Acculturation can happen naturally, when a certain culture is influenced by others, which are seen as dominant; or artificially, when these other cultures are imposed by social mechanisms such as consumption (Askegaard \& Ozcaglar-Toulouse, 2011; Luedicke et al., 2010). There are changes in the way individuals consume, or in their consumption preferences, when groups of individuals from different cultures have contact with foreign ones. This contact forces local cultures to some sort of mutation due to a process that can be uni-, bi- or multidimensional (Berry 1997; Segev et al., 2014). 
If, on the one hand, Brazil is a country with an emblematic cultural soft power, as for the ideological, identity and cultural influence, in exporting several cultural products (e.g., football, music, gastronomy) (Leão, 2018; Neto \& Sousa-Filho, 2016). On the other hand, its ethnocentrism, the characteristic worldview of those who consider their ethnic group, nation or nationality more socially important than the others, is fragile when compared to other cultures that historically have worldwide relevance (Juncklaus et al., 2016; Ma, Yang \& Yoo, 2020).

At this point, the U.S. stands out as the country that most seeks to hegemonize aspects of its culture (Bizumic, 2019). It is expected that the sports modality expressing the American culture with such force - the main reference of the country since the Second World War (Araújo et al., 2013; Motta et al., 2001) -, although it is not natural to Brazilians, would have a Brazilian audience involved with the culture it represents.

Accordingly, technological advancements and the participation in social networks are among the biggest catalysts of the multi-dimensions of acculturation: thanks to them, one culture is not necessarily subjected to another; they are mixed and negotiated by individuals who identify themselves with them (Canclini, 1995). Therefore, technological development can cause acculturation, because it allows foreign cultures to have direct and indirect impact on individual and collective social relationships set with cultures that exercise some sort of influence, which is multiplied, legitimated and exercised by the media (Askegaard \& Ozcaglar-Toulouse, 2011; Jenkins et al., 2002).

Thus, Brazilian NFL fans who engage in social media can practice American cultural aspects intrinsically related to American football consumption. Nevertheless, we present the following research question: How does the virtual interaction of Brazilian NFL fans during league game broadcasts reveal a consumption acculturation process?

Our study was built based on a semi-deductive logic, since it articulates concepts from the consumer research field to propose that the consumption of a foreign sports media league corroborates acculturation movements. Based on the understanding of the economic and cultural capacity of a major sports league like the NFL (Wenner, 2014), we focus on the virtual interactions of the audience that complement the transmission of the games in Brazil. Such interactions were revealed as fan practices, an interdisciplinary theme that, for consumer research, are understood as productive actions (i.e., prosumers) to the cultural object (Chen, 2018; Sugihartati, 2017). As the cultural object in question (i.e., NFL) is close to the culture of one of the countries that most makes use of its soft brand (Nye Jr., 2015), we understand this practice provides an acculturation of consumption (Segev et al., 2014).

Thus, we seek to expand how the consumption of an exotic cultural object can be expanded and naturalized by fans who continue in the context of Web 2.0. Specifically, our study addresses how negotiations between different cultures affect fans' consumption practices within a context where culture is seen as a distributed network, which is one of the perspectives of greater development in Consumer Culture Theory (CCT) on the current decade (Arnould \& Thompson, 2015).

\section{The prosumption of the fans}

The popularity of social networks lies on their ability to host a content based on viewers' participation, and its core is not more than daily life (Langlois, 2013; Jenkins, 2006). Individuals who act as consumers are no longer limited to the act of receiving information; they can file, give meaning, take possession and reproduce media content in an innovative way. Thus, there is no clear definition about where the commercial and standardized cultures start and end, since both are part of the participatory culture (de Souza-Leão \& Moura, 2018; Jenkins, 2006).

Individuals head towards a sense of community that gives them the sense of belonging by gathering to others in order to participate, discuss, receive or consume an object or specific good (de SouzaLeão \& Moura, 2018; Tombleson \& Wolf, 2017). Among members of participatory cultures, one finds fans who have been the focus of Social Sciences studies for more than two decades. This process results either from the culture they establish between themselves - capable of reaching new audiences - or from social spaces where this culture is established (Jenkins, 2008; Sandvoss, 2005). On the other hand, given consumers' ability to produce the goods they enjoy - which is not limited to the act of consuming - the participatory culture creates a bond that extrapolates consumers' traditional concepts (Hills, 2013; Jenkins, 2006).

This productivity derives from the spontaneous act of taking possession of, and reproducing, media texts; therefore, viewers become reproducers, ambassadors and exporters of the culture they are 
bonded to (Jenkins, 2006; Ritzer and Jurgenson, 2010). Following this reasoning, de Souza-Leão and Costa (2018) argue that fans are natural prosumers. Thanks to their consumption choices, some consumers become prosumers when they become part of the production process (Toffler, 1980). However, according to Ritzer and Jurgenson (2010), this role is not limited to incorporate functions to the production chain, because the technological advancement of Web 2.0 gave birth to a new class of prosumers, namely: individuals who do not need to be incorporated to the production of the good or service they consume, as long as they are able to produce such good or service through pro-active and dynamic acts (Huang et al., 2015; Samuel et al., 2018).

Prosumers aim at increasing the reach of products they consume when they share their viewpoints (Ritzer, 2014). Sports fans are natural prosumers (Santomier \& Hogan, 2013), since they often have positive influence on the performance of the teams they support, besides being responsible for generating monetization contents for these teams in Web 2.0 (Andrews \& Ritzer, 2018). Based on a broader sense, fans see themselves as active part of a heterogeneous group that gathers to share similarities. People in these groups understand that they are both the ones who receive and the ones who are responsible for the maintenance of the participatory culture they are members of (Jenkins, 2006; Sandvoss, 2003).

No wonder, the fan culture grew in the last decades because, nowadays, it is easier for fans to quickly meet and help each other, fact that makes it easier to create community strategies and, consequently, a shared consciousness focused on producing and sharing knowledge about the consumed culture (de Souza-Leão \& Moura, 2018; Guschwan, 2012). Therefore, the fan culture is complex and multidimensional, since it encompasses many participation methods and engagement levels (Sandvoss, 2005; Hills, 2013), besides giving importance and new meanings to aspects of local and global cultures. Accordingly, consumption acculturation processes are perpetuated by huge media conglomerates and by the globalization phenomenon (Cleveland \& Laroche, 2007; Gentry et al., 1995).

\section{Consumption acculturation}

The globalization phenomenon has been consolidating bilateral, dynamic and synchronous relationships based on how the consumption of local products and brands is influenced by the contact with foreign offers. This process, which results from the negotiation of many local cultures that have been resignified, makes the contemporary society establish a global culture (Kjelgaard \& Askegaard, 2006). In digital era, there is already an understanding that the use of social networks not only deterritorializes physical cultural barriers (Jenkins, 2008), but that the time used on such platforms can function as political practices (Jamal et al., 2019). Such an investment of personal time to deal with political aspects improves the self-efficacy of individuals and resonates their perception of what culture is (Bandura, 1997; Kiang, Glatz \& Buchanan (2016)).

It's a phenomenon which happens through consumption acculturation, when individuals from different cultures have contact with consumption habits of other cultures, fact that changes their communities and the culture they are part of (Berry 1997; Segev et al., 2014). This phenomenon is known as acculturation, broadly used in Social Sciences to help better understanding immigration and changes resulting from crossings between different cultures (Berry, 1997; Ha et al., 2014).

The typology proposed by John Berry (1997), which describes four strategies to explain how individuals face a new culture, has been widely adopted given its influence on consumption (Jamal et al., 2019; Kizgin et al., 2018; Smith \& Khawaja, 2011): assimilation and integration are adhesion forms, whereas marginalization and separation are exercises of resistance. Therefore, assimilation refers to the choice made by some individuals for adopting a foreign culture (values and traditions) for a certain period of time, while they gradually lose their interest in their native culture; integration happens when there is the interest in maintaining the native culture, despite the daily contact with a new one; marginalization refers to the individual's will to reject the foreign culture, although they do not exalt the local one; and separation concerns the exaltation of the local culture in order to deny the foreign culture this individual has contact with.

Consumption acculturation mimics different features of its members and is assessed based on different references: the influence on personal preferences, needs, attitudes and behaviors (Alden et al., 2006); the help in developing identities based on consumption (Belk et al., 2013); and promoting values that guide people's daily activities (Chernev et al., 2011; Luedicke et al., 2010). According to these as- 
pects, the consumption of global cultures is boosted by consumers capable of building identities unbound to nations and physical territories but bonded to elements seen as vital to day-to-day life. These elements can be provided by the different cultures that consumers are proud to widespread (Sobol et al., 2018).

Consumers are part of the process to maintain a culture when they share their impressions about it (Berry, 2008; Segev et al., 2014). This process explains how individuals keep the features of their own culture while consuming new ones, whereas they introduce a new culture for the ones who would not have the chance to know it. They do so by exercising an acculturation that ends up playing a productive role in consumption flow (Askegaard et al., 2005; Cruz \& Buchanan-Oliver, 2017). Accordingly, it is more usual to maintain a native culture in private life (food, music, clothing, celebrations) than to get to know other cultures in public domains (school and work environments, social networks) (Martin, 2012; Peñaloza, 1994) where individuals exercise consumption acculturation by negotiating different cultures (Arends-Tóth \& Van de Vijver, 2008; Jamal, 2003; Kizgin et al., 2018).

The productive and symbiotic relationship between different cultures was called 'hyperculture' by Askegaard et al. (2005). This relationship happens when a minority of expert consumers (fans, prosumers) uses aspects of the culture they are bond to in order to commodify the dominant culture acculturating them. These authors describe the hybrid culture as resulting from consumption communities formed by the relationships their members establish with each other, by the consumption of brands and services, by the performance of shared activities and by the ability to build a sense of consumption to be replicated (Arnould and Thompson, 2005; McAlexander et al., 2002). Some brands establish such a strong relationship with local cultures that, when they expand to new markets, they need to adjust to the new culture and, in some cases, they even have to associate with local rituals (Batra et al., 2012; Sharma et al., 2017). This association happens because brands intrinsically related to a certain culture tend to practice multiculturalism to expand their markets; thus, they encourage the acculturation of individuals belonging to the culture they now interact with (Zhang, 2009).

\section{Methodology}

The present investigation is a field study that looks at a community of practice (Wenger, 2001) based on consumer interactions (Mutch,2003). The study followed the netnographic design, also known as virtual ethnography, since it enables investigating social exchanges between consumers, mainly in virtual environments, and the reflex of these exchanges on the online and offline world (Hamilton \& Alexander, 2017; Izogo \& Jayawardhena, 2018). It happens because this ethnography is adapted and flexible based on researchers' interests (Caliandro, 2014; Kozinets, 2002). Netnography focuses on observing the way informational and social communications and connections happen based on their main contribution in comparison to other ethnographies: revealing how online organizations and cultural forms take place, as well as boosting the discussion about how these forms are maintained and changed (Colliander \& Hauge Wien, 2013; Kozinets, 2010; Underberg \& Zorn, 2013); mainly, the method used to investigate the preferences of media sports consumers (Filo et al., 2015; Næss, 2017; Stavros et al., 2014).

We used the method according to procedures indicated by Kozinets $(2002 ; 2010 ; 2015)$, who has a broader approach in this field. Netnography follows three stages: Cultural entreé, which concerns researchers' familiarization with the investigated context, so that they can understand the assessed reality from the viewpoint of their participants; data collection, better known as the process of observation and monitoring of online discussions by saving and filing the texts. Also, researchers can elaborate field notes responsible for the assessed process in order to complete and detail the research corpus; and data analysis and interpretation, last stage conducted through codification, reflection, abstraction, comparison, checking, refinement and theoretical generalization, and, whenever possible, through the theorization of the research corpus.

Researchers have been watching NFL games since 2009, and one of them also uses his Twitter account to interact during league-games since 2010; therefore, he became part of this online community. Besides, he plays American football in Brazil since 2012, and acts in the national tournaments. Such practice led him to strengthen ties with other consumers in the league and, mainly, use his social networks to interact about it. In an axiological positioning, our role as researchers is that of acafans: those who recognize the influence of their emotional connection with the objects from popular culture consumed in the choice of their academic productions, but who conduct the investigation following ethical 
and scientific procedures (Cristofari \& Guitton, 2017).

To access this culture, we monitored the online community of Brazilian NFL fans that interacts on ESPN channels' Twitter about the league news and broadcast. Brazilian ESPN broadcast NFL games since September 1992 and currently holds exclusive rights for broadcasting the league in the country (Firmino, 2018; Francischini, 2018). The platform hashtags launched by ESPN Brasil are, simultaneously, the main means of interactions between sports fans and the official communication for the audience to participate in the league's national broadcasts (ESPN, 2017).

Four Twitter hashtags were used to collect data: \#TudoPelaNFL, \#PlayOffsNFLnaESPN \#SuperBowlnaESPN - concerning the 2016-17 season - and \#NFLnaESPN - used in 2017-18 and 2018-19 seasons. Each tweet (e.g., text message, photos, GIF videos, hyperlinks) from viewers' interactions posted in those hashtags was filed manually, saving the contents of the web browser to PDF files during league games broadcasted by ESPN channels in Brazil for three years. This corresponds to the coverage of 418 games, in total: 119 in the first season, 141 in the next and 138 in last one. In all, more than two million messages were collected. Such number of messages were organized by date of transmission. At the same time, field notes were produced to guide and facilitate the analysis process. Still, the interactions between ESPN channels and audience during broadcast games were also recorded as a reference to understand the subjects discussed in Twitter messages.

Data analysis was divided in three stages, based on the ones highlighted by Kozinets $(2010 ; 2015)$. From a manually analytical coding (i.e., without any software), we gave temporary code names to data of the corpus in order to develop the ultimate data classification and hierarchization (codification and reflection). Next, after data were already codified, we filtered and classified them in order to generate the clearest and truest identifications and relationships, and to formulate the categories (abstraction, comparison and checking). Finally, we elaborated a set of general meanings based on the codes and categories that have emerged during the previous stages. Therefore, it was possible to describe data consistency based on the literature (theoretical generalization).

We conducted the investigative process by taking into account quality criteria described in qualitative research, such as that by Kozinets (2015) for netnographic research. These criteria regard data saturation, axiological arguments set in the cultural entreé, researchers' reflexivity and respect to the observed praxis. As our data is obtained from a social media, we take some precautions to achieve the ethics of an ethnographic work proposed by Kozinets (2002). Twitter is an open platform known to be used to gain a better understanding of its users, their acts and impacts on society and culture from various perspectives (Weller et al., 2014; Zimmer \& Proferes, 2014). It provided secondary data in the public domain, as it is a social network with usage policies that oblige its users to make their publications public or private. For analysis purposes, we use only those which are public and available from the social network for at least 12 months (Fernandez Espinosa \& Xiao, 2018). Also, as it can be seen in the results section, the data in which the fans appear (i.e., tweets with photos) were blurred precisely for the sake of ethics and to maintain their anonymity.

\section{Results and discussion}

We identified nine codes related to the acculturation process faced by Brazilian NFL fans. The codes found demonstrate that these are close and converging issues. In this regard, the next analytical level became evident: the categories, where the commonality of codes is observable. In this sense, the nine codes were organized in three categories, which are presented based on the empirical context of the research and introduced according to the literature.

\subsection{Comparison between Brazilian and American NFL features}

American football is the sports modality that best reflects the American culture (Axelrod, 2001; Oates \& Furness, 2014), since it represents many social, economic, ethical and patriotic practices that were institutionalized by the American nation (Wenner, 2014). NFL outspreads the positive values of this culture worldwide given the way it is set for global broadcast (Davis et al., 2014).

The consumption acculturation process involves a certain degree of cultural amnesia in which part of a society negotiates an exchange, i.e., individuals make the option for forgetting local aspects by consuming a foreign culture. Such cultural amnesia is the replacement, or change, of a mostly negative sense of historical reality or local policy (Granot et al., 2014; Jenkins et al., 2002). 
The present category evidences how Brazilian NFL fans exchange American cultural aspects intrinsic to the consumption of league games, which are broadcast, based on cultural aspects of their own country, by virtually interacting with each other. Such process is boosted by the negative perception of Brazilian viewers about their local culture to the detriment of an apologetic view about the American culture.

\begin{tabular}{|c|c|}
\hline $\begin{array}{l}\text { \#tudopelanfl Mesmo com esse jogo fraco, eu nåo troco } \\
\text { NFL pela Seleção brasileira. } \\
\text { Transiate tweet } \\
\text { 12:01 AM . Oct 7, } 2016 \text { from Baixo Guandu, Brasil . Twitter for iPhone }\end{array}$ & $\begin{array}{l}\text { Mano já sou loka com futebol brasileiro agora tô } \\
\text { ficando loka com o americano legal né } \\
\text { \#NFLnaESPN } \\
\text { Thunate Twear } \\
\text { 9:13 PM. Feb 3,2019. Twitter for Android }\end{array}$ \\
\hline $\begin{array}{l}\text { As zebras estäo cada vez piores. Está chegando no nivel } \\
\text { da arbitragem do futebol brasileiro. \#NFLnaESPN } \\
\text { Tranaiats Tweet } \\
\text { 8:13 PM - tan 20, } 2019 \text {. Twitter for Android }\end{array}$ & $\begin{array}{l}\text { assistir futebol brasileiro?? to fora } \\
\text { pego meu football e vou embora \#NFLnaESPN } \\
\text { Thaniatw Twat } \\
11: 03 \text { PM. Sep 7, } 2017 \text {. Twitter for iPhone }\end{array}$ \\
\hline $\begin{array}{l}\text { O futebol Brasileiro deveria se espelhar na Organização } \\
\text { e recursos usados no Futebol Americano. } \\
\text { \#TudoPelaNFL } \\
\text { Transiat twent } \\
11: 17 \text { PM. Oct } 30.2016 \text {. Twitter for Android }\end{array}$ & $\begin{array}{l}\text { Hj tem futebol em horário de nfl... isso é ciúmes? } \\
\text { \#tudopelanfl \#SelecaoBrasileira \#SelecaoSportv } \\
\text { Trandate Twevt } \\
1128 \text { PM. Nov 15, 2016. Twitter for Android }\end{array}$ \\
\hline
\end{tabular}

Figure 1. Comparison between the NFL and Brazilian major sport

Source: research corpus, available from https://twitter.com (Re-accessed in May 21, 2020).

The first code in this category unveils how Brazilian NFL fans value American football, not just because of its sports features, but because it is seen as a media spectacle associated with the American culture. Such concept makes these viewers rue that football association broadcasts - the emblematic sports modality of the national culture - does not have the same appeal. Fan messages that illustrate this aspect were gathered in Figure 1.

\begin{tabular}{|c|c|}
\hline 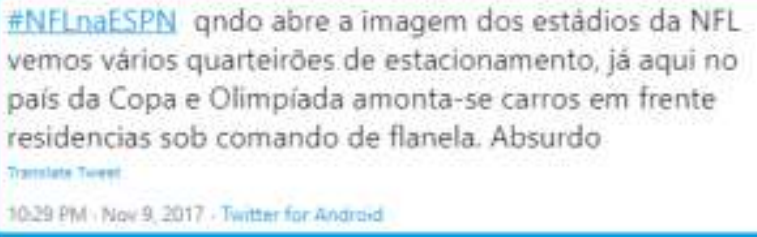 & 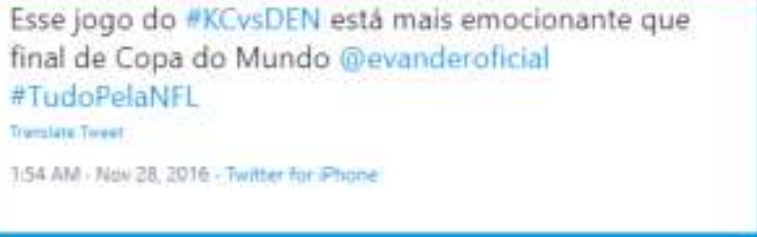 \\
\hline 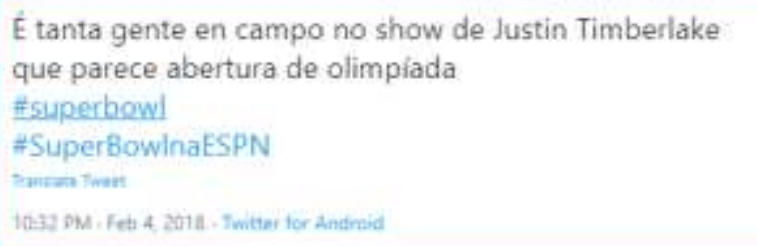 & 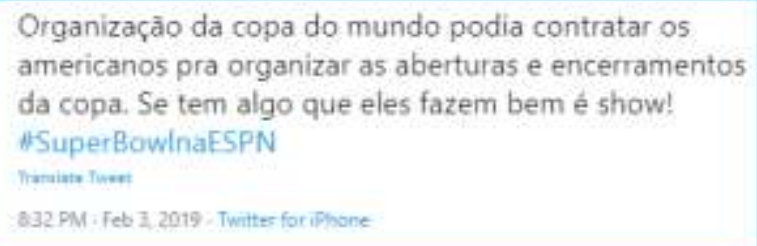 \\
\hline 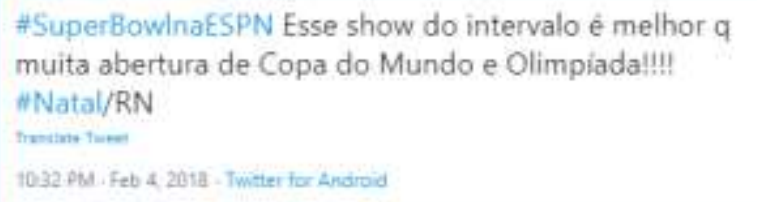 & 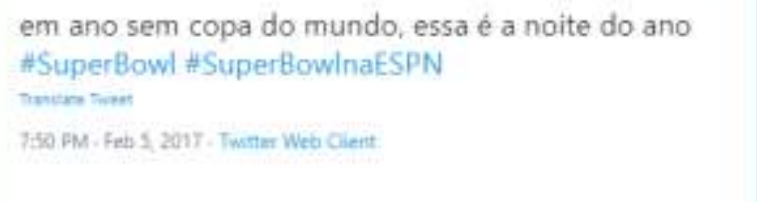 \\
\hline
\end{tabular}

Figure 2. (NFL) U.S. events are compared to Brazilian ones

Source: research corpus, available from https://twitter.com (Re-accessed in May 21, 2020).

In a similar way, the second code expresses how these fans see the league and, most of all, the Super Bowl, as emblematic example of the American ability to organize events, fact that is also related to the culture of this country. Comparison to Brazil includes, but also goes beyond, football association, as it calls the attention to great global events that recently took place in the country, like the 2014 World Cup and the 2016 Olympics. These events were acknowledged for structural issues that had political and economic reflects on the nation. We selected tweets (Figure 2) to illustrate this aspect. 


\subsection{American rituals embodied by Brazilian NFL viewers}

Brands that bring along the culture of a specific location can be seen as exotic to different cultural contexts, but they aim at changing the assumption that they are strange to certain local cultures. Moreover, these brands use to be associated with rituals of local cultures or to create new ones (Batra et al., 2012; Sharma et al., 2017). Foreign brands put multiculturalism in practice by linking themselves to already existing rituals of a culture. This multiculturalism evaluated to which extent a society opens itself to new rituals by discharging or changing its own rituals (Zhang, 2009).

The NFL brand is very representative of American values, besides highlighting some rituals of the American culture. Based on the scope set for the present study, the idea was not to assess whether this brand encourages practices in Brazil that associate aspects of the American culture with the Brazilian one. However, we evidenced how Brazilian NFL fans mimic rituals inherent to the U.S., which are typically exercised by American league fans while they consume its games.

The first code of the category regards the consumption of one of the richest aspects of a culture: its cuisine. Brazilian NFL fans post pictures of, and comments about, the typical American dishes they eat while they watch NFL games (e.g., hamburgers, hot-dogs, buffalo wings), as well as of products produced by food brands easily acknowledged as American (e.g., Budweiser, Jack Daniels). Interactions about this topic can be seen in Figure 3, which characterize the experience of watching NFL games while having such typical American snacks, food, and beverages.

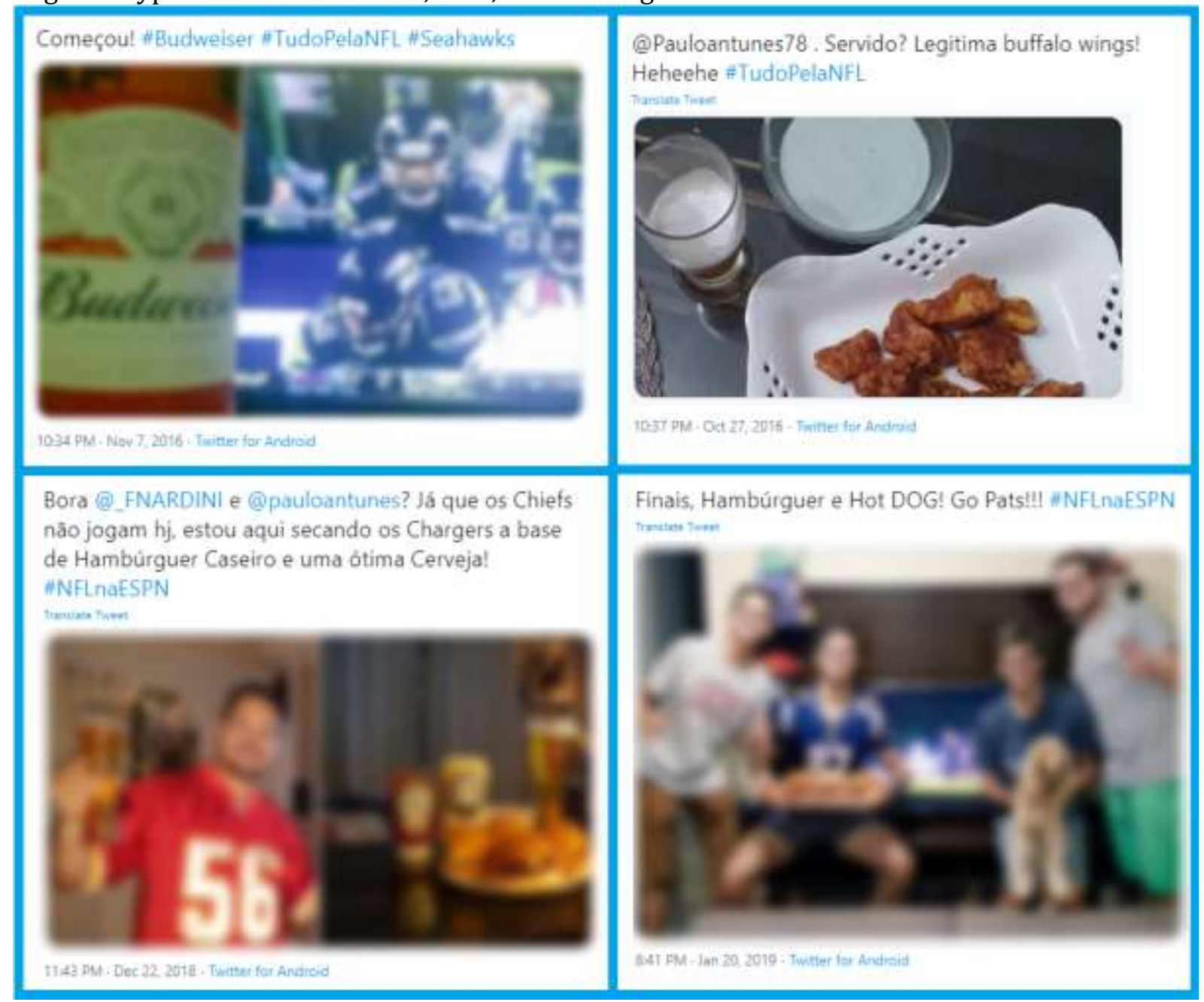

Figure 3. American rituals imported into NFL consumption

Source: research corpus, available from https://twitter.com (Re-accessed in May 21, 2020).

Similarly, the second code shows how NFL viewers in Brazil experience American holidays that are not traditional to the Brazilian calendar due to the league. It is the case of Halloween, when games broadcast in the last week of October present features of this time of the year in the U.S. and encourage NFL fans to put their costumes on to watch the game on this holiday. The three games broadcast in 
Thanksgiving, and all shows broadcast throughout this day, mention this celebration. Brazilian fans respond to the Halloween invitation by posting pictures in which they are wearing their costumes and by arguing that Thanksgiving should be a holiday in Brazil, so they could celebrate it and watch the games. Figure 4 shows tweets with photos of fans celebrating U.S. holidays while watching the NFL.

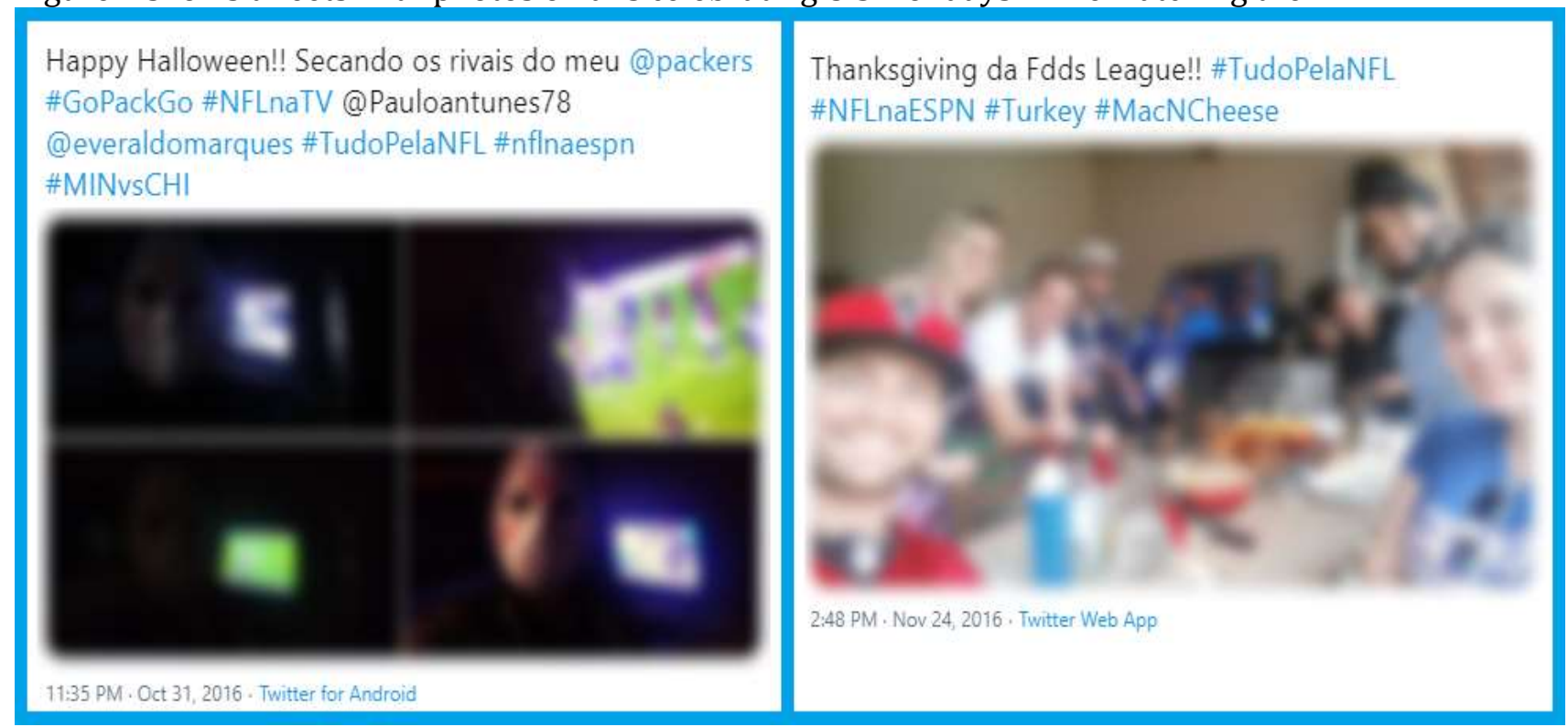

Figure 4. American holydays imported into NFL consumption

Source: research corpus, available from https://twitter.com (Re-accessed in May 21, 2020).

It is common to American NFL fans to get together with relatives and friends to watch league games (Clark et al., 2009; Sandvoss, 2003). The third code of this category evidences that Brazilian fans do the same. They widespread how American football is a sports modality to be watched with companions. The Super Bowl stands out in this practice, and highlights countless comments of Brazilian fans about how the first Sunday of February should be a holiday for the family in Brazil, just as it happens in the U.S. It is also possible finding records about the number of years these comments have been made in order to feature the tradition. We elaborated Figure 5 with photos of these moments.

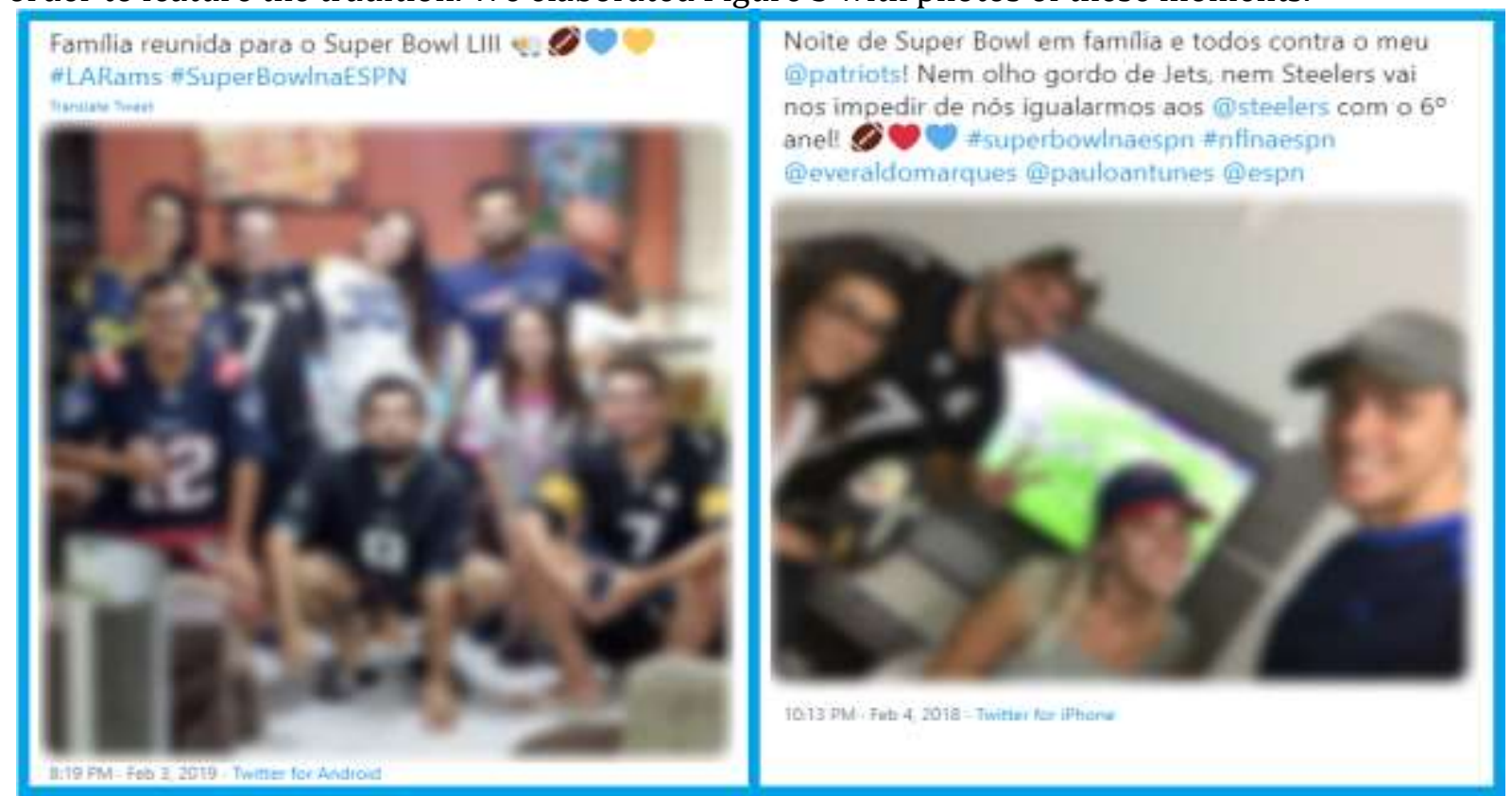

Figure 5. Super Bowl is already a family tradition for the Brazilian audience

Source: research corpus, available from https://twitter.com (Accessed in May 21, 2020).

Overall, the habit of watching NFL games with friends and relatives become a celebration. Usually, American fans get to stadium surroundings hours before the game in order to socialize, while supporters 
drink and eat, during an event known as tailgate (Veri \& Liberti, 2013). Supporters organize parties during the game, honoring the American flag, and counting on the presence of cheerleaders and team mascots in order to watch the games (Axelrod, 2001). The last code of this category highlights the parties organized by Brazilian NFL fans who watch the games together, mainly the Super Bowl, and who post pictures of great repercussion in the community. In order to follow the steps taken by native league fans, these parties have the tailgate vibration, honor the American flag and count on cheerleaders and team mascots, as seen in the tweets in Figure 6.

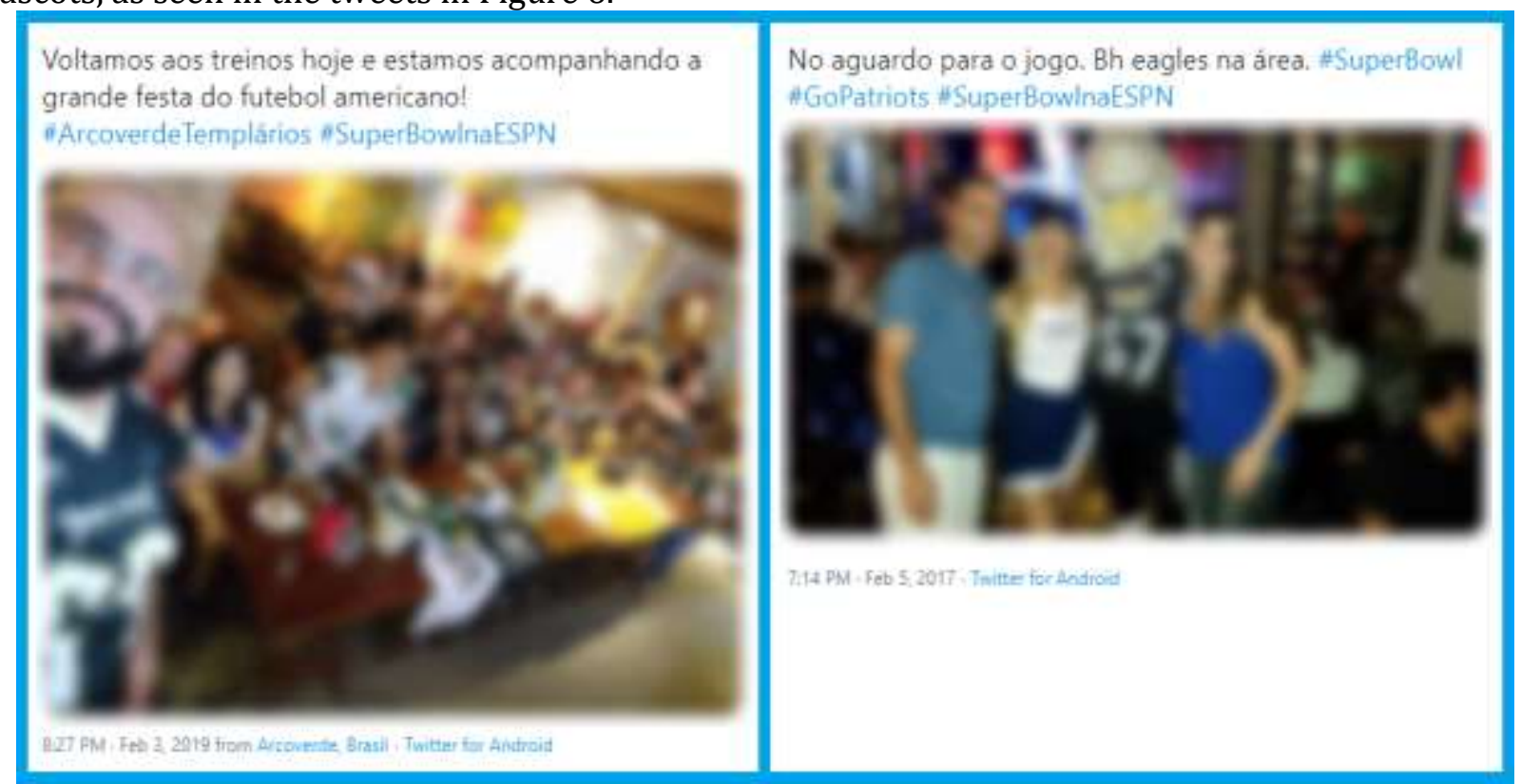

Figure 6. Super Bowl is consumed at NFL-related parties

Source: research corpus, available from https://twitter.com (Re-accessed in May 21, 2020).

\subsection{The routine of NFL Brazilian fans changed due to time zone}

The acculturation process is made easy by the relationship between consumers' public and private lives; whereas, the local culture is most easily maintained by the ordinary choices of private life (e.g., clothing, slangs) and foreign cultures tend to be exalted in public life (social networks, school and work environments). Thus, the individual tends to be suppressed by the socially established dominant culture (Arends-Tóth \& Van de Vijver, 2008; Jamal, 2003; Kizgin et al., 2018), and it includes aspects such routine maintenance, which derives from a foreign culture that embodies different meanings for each individual who is not natural to it (Berry, 1997).

NFL broadcasts are formed and based on the schedule and calendar of the location seating the game and of its main viewers: U.S. When fans of this sports modality in Brazil adhere to the consumption of the main American football league they need to deal with schedules and dates that are not natural to them and to reveal routine changes during the NFL season - fact that has consequences in their social lives.

One of the codes in this category expresses how NFL fans in Brazil engage in expectations about important data of the league season. This feeling is common to Americans, given the vibration felt in the country during these occasions, which gain special meaning for Brazilians who follow the league, since such process generates a sense of belonging in fans in this community. The kickoff, which is the game opening the regular league season in the first Thursday of September, is anticipated by comments that express great anxiety, mainly because they break the six months fast on games between seasons. This buzz is only overcome by the expectation for the Super Bowl. This same feeling is felt during the playoffs - eliminatory games that determine the way towards the finals - and remarkable dates, mainly Christmas and New Year's Eve, when the game rounds define the teams classified for the post-season. Fan tweets that exemplify this aspect were gathered in Figure 7. 


\begin{tabular}{|c|c|}
\hline 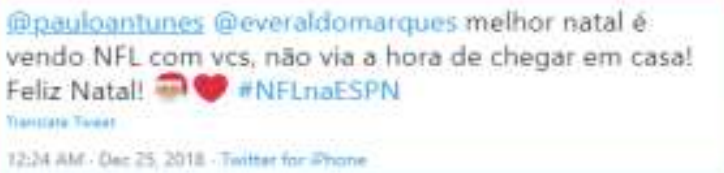 & $\begin{array}{l}\text { Chegando agora na \#NFLnaESPN e desejando Feliz } \\
\text { Natal ao (1) everaldomarques, @ManchaNFL e toda } \\
\text { equipe q nos traz esse jogo em ritmo de festa. } \\
\text { Nww } \\
11115 \text {. }\end{array}$ \\
\hline $\begin{array}{l}\text { Eu esperei } 7 \text { meses por hoje, essa ?a hora parece } \\
\text { demorar anos pqp! } 1 \text { Kickoff "NFLKickoff2017 } \\
\text { "NFLNaESPN }\end{array}$ & $\begin{array}{l}\text { \#NFL naFSPN NFL e Vida um grande presente da ESPN } \\
\text { para nos Feliz Natall Marcio e Diego } \\
627 \text { FM . Dec } 24 \text {. } 2017 \text { - Twinter far imone }\end{array}$ \\
\hline 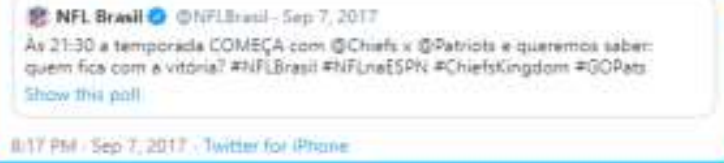 & $\begin{array}{l}\text { (1) romulomendonca Já começou a festa de Ano Novo } \\
\text { mas só saio de casa para a festa depols do jogo } \\
\text { \#GoSeahawks \#NFLnaESPN }\end{array}$ \\
\hline Parece que to comemorando ano novo com frases tipo & 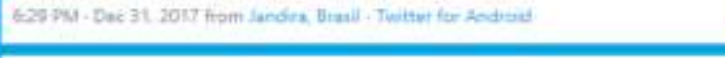 \\
\hline $\begin{array}{l}\text { "primeiro banho do ano": "primeira falta da temporada" } \\
\text { "primeiro punt da temporada" "primeiro sack da } \\
\text { temporada" \#NFLnaESPN } \\
\text { Thumm }\end{array}$ & 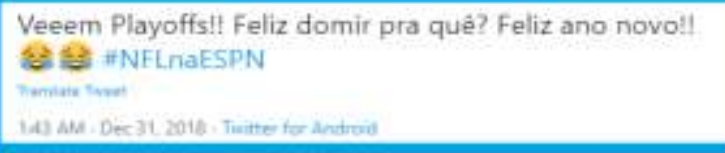 \\
\hline 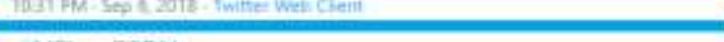 & enfim chegou a noite mais aguardada do ano \\
\hline $\begin{array}{l}\text { \#NFLnaESPN } \\
\text { (everaldomarques } \\
\text { (1) pauloantunes }\end{array}$ & 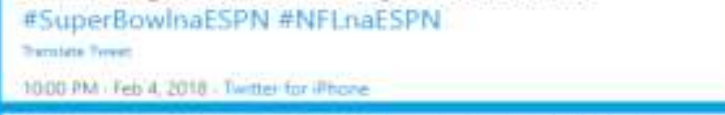 \\
\hline 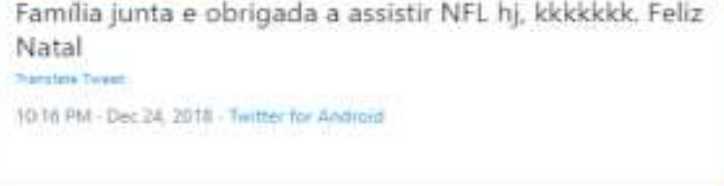 & 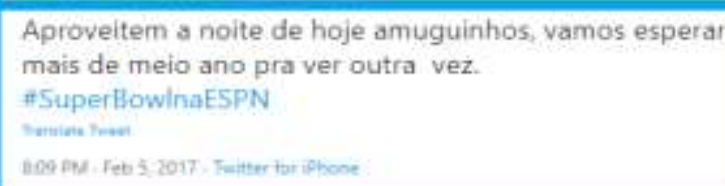 \\
\hline
\end{tabular}

Figure 7. Key moments of the NFL season overlap with the lives of their fans

Source: research corpus, available from https://twitter.com (Re-accessed in May 21, 2020).

Another identified aspect (code) regards how Brazilian NFL fans see league game days as an important appointment. They even change their week schedule and skip social events during the league season. Game days and schedules (i.e., Mondays and Thursday's nights and Sundays afternoons) are taken seriously, tweets report how Brazilian fans stop going to social events (e.g., birthday parties, family meetings) and even skip enjoying Brazilian summer Sundays and Carnival, which is the most emblematic festival of the Brazilian culture. Figure 8 brings tweets which can illustrate this aspect.

\begin{tabular}{|c|c|}
\hline $\begin{array}{l}\text { Quase morri } 1 \text { mas q aniversário sensacional todos } \\
\text { meus times amados ganharam e o chocolate belga do } \\
\text { meu bolo foi Patriots campeà AFC e SB! heheheh e } \\
\text { acertei q seria Patriots vs Rams no \#SBLIII } \\
\text { is \#Esprileague \#NFLnaESPN } \\
\end{array}$ & 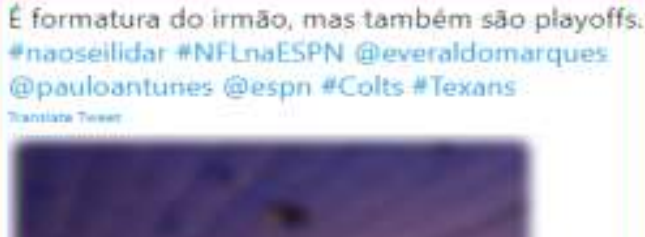 \\
\hline $\begin{array}{l}\text { бeveraldomaraues comemorando aniversário de } \\
\text { casamento deitado na sala com a esposa torcendo pelo } \\
\text { PATRIOTS \#TudoPelaNFL. } \\
10 \text { a }\end{array}$ & \\
\hline 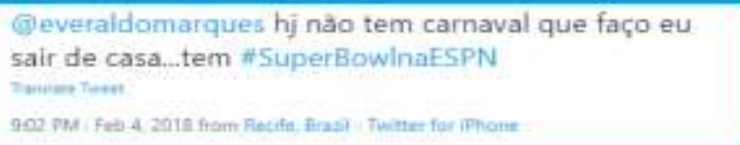 & \\
\hline $\begin{array}{l}\text { "Super BowinaESPN } 450 \mathrm{~km}, 5 \mathrm{hrs} \text { de estrada, saindo } \\
\text { cedo da praia em fim de ferias p chegar em casa em } \\
\text { tempo do SB. }\end{array}$ & \\
\hline 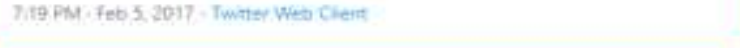 & \\
\hline
\end{tabular}

Figure 8. Key moments in the life of Brazilian NFL fans need to adapt to league games Source: research corpus, available from https://twitter.com (Re-accessed in May 21, 2020). 
Finally, the last code of the present category indicates how Brazilian NFL fans change their schedules in order to watch the league games. Broadcasts in the country are not good to viewers in Brazil due to time zone, since most games start at the American winter time and at the Brazilian day-light-summertime. Night games, which last longer than three hours, go through the night. Tweets reproduce the jargon created to watch the NFL in Brazil: NFL is for the strong ones - for the ones who are brave enough to resist their sleep and who deal with such short sleep in their work productivity in the day after. Netizens in Southern and Southeastern Brazil - the most developed regions in the country, which concentrate most NFL viewers - point out the privilege of people living in Western regions who live in a time zone closer to the American one, and of the ones living more to the Northern regions, who do not have to change their time zone in summer. The messages in Figure 9 show how the routine of Brazilian NFL fans is affected when they dedicate themselves to watching league broadcasts that can reach three hours in length.

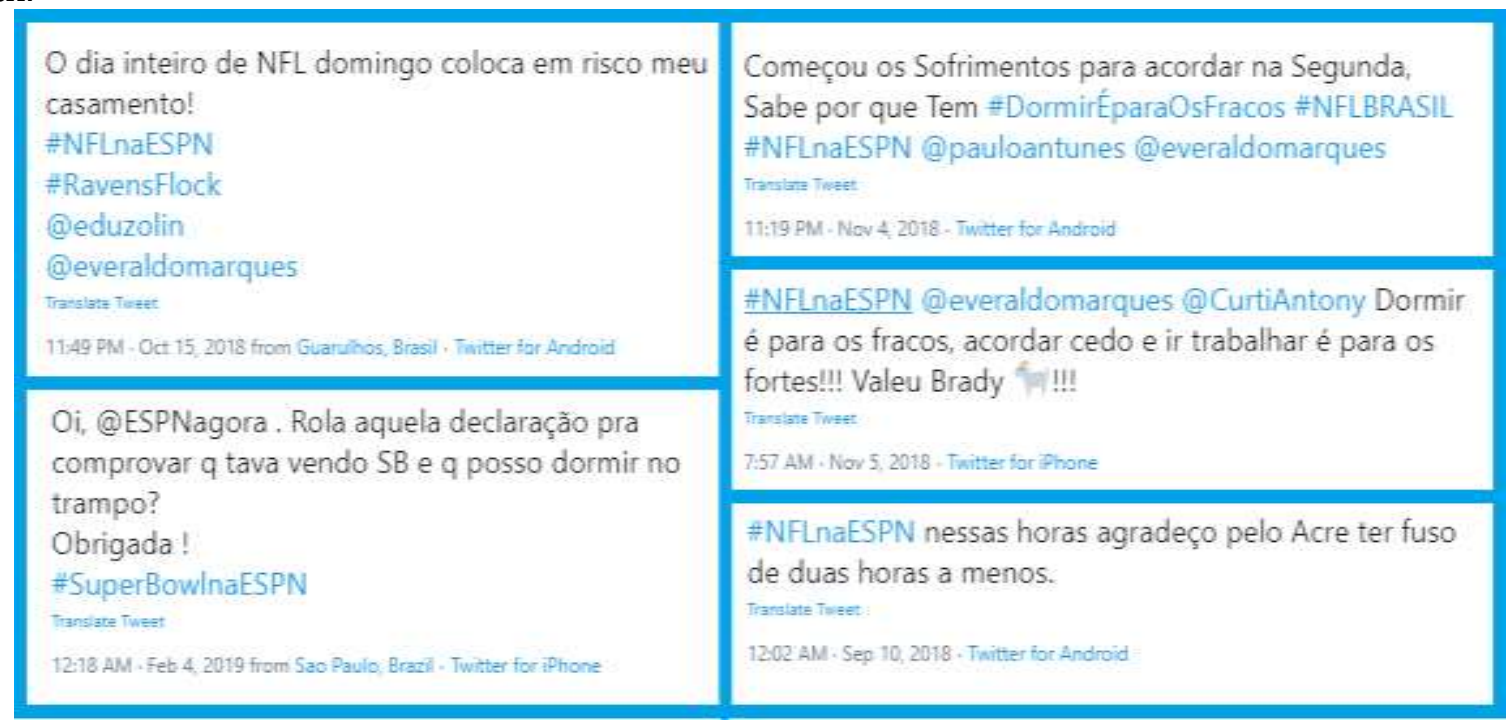

Figure 9. Impact of NFL broadcasts on the routine of their Brazilian fans

Source: research corpus, available from https://twitter.com (Re-accessed in May 21, 2020).

\section{Reflections from results}

It seems to us that such a combination of cultures is based on a social dispute based on the differentiation operated between cultural capital and economic capital. From the notion of the soft brand (Neto \& Sousa-Filho, 2016; Nye Jr., 2015), it is possible to see the valuation of cultural aspects for NFL fans in Brazil. When they combine the strengths of domestic culture with those of the foreign sports league, they attest that the place should not be ignored. On the other hand, the incorporation of foreign values and rituals indicates an exaltation of what comes from outside. Finally, the mixture shown in the adaptation of the Brazilian routine to that of the USA reveals a non-oppressive hierarchy between such cultures.

All three are the consumption acculturation strategies highlighted by Berry (1997). In this sense, we identified the strategies capable of valuing a foreign culture. The comparison and ritualization pointed out an integration process, to the extent in which a foreign culture is reproduced from the understanding that it is better than the native one. The practice of comparing the Brazilian and American cultures by Brazilian NFL fans evidences their original culture and their will that their own culture could repeat aspects of the foreign one, which is seen as better, so that it must be reached by the local one. Similarly, the incorporation of American rituals is evidenced by the exaltation of the American culture; however, due to the way they are introduced, these rituals are a sui generis appropriation lined to a certain end. This approach also features this practice as an assimilation process, since it does not highlight the total rupture with the original culture, although it is possible seeing such a distancing at the long-term period. Accordingly, changes in daily routines evidenced in our research do not feature a complete lifestyle change, but a punctual adjustment limited by certain circumstances that, certainly, have important social implications.

Another classic author regarding contributions to acculturation, Bandura (1997) proposes a theory which indicates how the relationship with cultural aspects is a result of social (i.e., family, friends) 
and cognitive (i.e., self-efficiency) experiences. As an expansion of this concept Kiang, Glatz and Buchanan (2016) focus on U.S. culture, considering that there is socialization listed at three cultural levels: the combination between different cultures, the exaltation of the American way of life and family heritage. Our results are equivalent to each of these levels. It's an entertainment process that takes place thanks to the common sense, which is multiplied when aspects of the consumed culture are used to resignify and to reflect about the culture one makes part of (Askegaard et al., 2005). On the other hand, rituals are relevant for a nation to the extent that they express its way of thinking and feeling (Wallendorf \& Arnould, 1991). Moreover, they work as a way to naturalize individuals from other countries and ethnicities (Ustuner \& Holt, 2007; Peñaloza, 1994). The embodiment of American rituals by Brazilian NFL fans reflects how they symbolically negotiate the American culture in their reality in order to feature how they absorb it during NFL games. Finally, by changing their schedules during part of the year due to the American time zone, Brazilian NFL fans subject themselves to an alien cultural pattern to the detriment of their own (Granot et al., 2014; Jenkins et al., 2002).

The fannish way to incorporate cultural values from massively mediated entertainment objects makes economic notions fused with cultural ones (Chen, 2018; Jenkins, 2008). It is a movement that continues to hegemonize the values of a culture that already has a global reach (Nye Jr., 2015), as it is linked to the interests of the entertainment industry (Jenkins, 2006).

Thus, it seems to us that the acculturation of consumption present in entertainment objects is close to Pierre Bourdieu's concept of cultural domination. In his conception of shock between cultures, Bourdieu $(1997 ; 2005)$ considers that every mixture of cultural aspects evokes a relationship of forces by which the strongest link maintains continuous sub-submission to the weakest link. There is no benign mix of cultures: economic interests are intrinsic to overlapping those of culture. This clash between cultures represents the confrontation of two closed social systems in asymmetric relations of material and symbolic power. It is a heuristic model that, despite causing change on the two sides that are part of the process, presents a strategy of rationalization of the hegemonic culture present in the trajectory that is beyond any objectivist homogenization.

\section{Final considerations}

Findings in our research show the consumption acculturation process of Brazilian NFL fans based on their virtual interactions during league-game broadcasts according to three practices: the comparison between Brazilian and American features, the embodiment of American rituals and schedule changes in order to adjust it to the times of game broadcasts. Brazilian NFL viewers set a symbiotic relationship with their native, and other cultures, by comparing and embodying features of a culture other than the native one, and this process generates a hybrid culture. It is a consumption acculturation allowed by virtual interactions on social media; an acculturation of consumption that is possible due to the close relationship between sports and cultures, but mainly due to the intensity of the virtual interactions that NFL broadcasts in Brazil stimulate in their audience.

The way which Brazilian fans found to enjoy league-games as a singular and culturally significant experience complies with the familiarization and valuing of the American culture in the country. Thus, the consumption productivity of American football is evidenced by the way the culture involving it is appropriated during negotiations with the cultural context in which consumption takes place. Such fact can result either in the simulation of the American culture or in the establishment of the ideal Brazilian culture.

Our research shows how a virtually mediated social interaction establishes the ideal virtual environment for practices that give meaning to consumption based on viewers' viewpoints. It also presents how this environment - which is culturally de-territorial - assures the necessary conditions for cultural appropriation and re-signification. Thus, the factor we point out as an acculturation process gains the profile of a hybrid cultural amalgam. We also evidenced the core role played by entertainment in current cultural processes by describing, in details, how it happens due to consumption practices exercised by media sports viewers.

From our reflection of the results, we conceived that the interactive consumption of Brazilian NFL fans leads them to participate in an acculturation movement. The overlapping values of different cultures propagated by fans reveal how they pursue values of cultural objects. Such productivity to the cultural values of the NFL is, simultaneously, possible and consequent of an active participation typical of fans who, through appropriation of available technology, converge between media and to relate with 
similar individuals about cultural objects.

It is worth pointing out that the research design represents both a scope and a limitation: if by focusing on Brazilian NFL viewers engaged in social networks we neglect the ones who do not act this way, we access a kind of cultural production that corresponds to the most participative audience of media texts (Jenkins, 2008).

In this sense, our study is aligned to the perspective that in recent years the intense use of social networks to deal with issues related to consumption provides a rich source of information for marketing professionals (Felix, Rauschnabel, \& Hinsch, 2017; Perdigão et al., 2016). Exploring the use and the way consumers interact with products and brands through social networks provides reliable information for these professionals (Tenconi \& Cancellier, 2016), especially when that information is presented through theoretically based interpretations. Thus, the concepts presented in our study adds, on a general level, to the understanding of how the analysis of the use of social networks about prosumerist practices can help marketing professionals (Marques \& Frederico, 2018). At the specific level, the importance of interactions of media sports' fans reveal opportunities for professionals working in this market (Dixon, Martinez, \& Martin, 2015).

Finally, we saw future outcomes of the present study such as investigations about how fans from other cultures - traditionally susceptible to external influences - take possession of culturally designed media sports modalities, and how these modalities can become popular in such cultures. Especially, those ones which have a focus on U.S. sports leagues (i.e., NBA, MLB) with consumption resonance in several countries of the world.

\section{Acknowledgements}

National Council for Scientific and Technological Development (CNPq) supported this research.

\section{References}

Alden, D. L., Steenkamp, J.-B. E. M., \& Batra, R. (2006). Consumer attitudes toward marketplace globalization: Structure, antecedents and consequences. International Journal of Research in Marketing, 23(3), 227-239.

Allen, J. T., Drane, D. D., Byon, K. K., \& Mohn, R. S. (2010). Sport as a vehicle for socialization and maintenance of cultural identity: International students attending American universities. Sport Management Review, 13(4), 421-434.

Andrews, D. L. and Ritzer, G. (2018). Sport and prosumption. Jornaul of Consumer Culture, 18(2), 356373.

Araújo, B. F. V., Teixeira, M. L. M., \& Malini, E. (2013). Estrangeirismo e Complexo de Gulliver: Brasileiros na percepção de expratriados de diferentes origens. Organização \& Sociedade, 20(66), 461-478.

Arends-Tóth, J. V., \& Van de Vijver, F. J. R. (2008). Family relationships among immigrants and majority members in Netherlands: The role of acculturation. Applied Psychology An International Review, 57(3), 466-487.

Arnould, E., \& Thompson, C. J. (2005). Consumer culture theory (CCT): twenty years of research. Journal of Consumer Research, 31(4), 868-882.

Arnould, E. J., \& Thompson, C. J. (2015). Consumer Culture Theory: Ten years gone (and beyond), in A. Thyraff, J. B. Murray, \& R. W. Belk (Org.). Research in consumer behavior (pp. 1-21). Emerald Group Publishing, Bingley, UK.

Askegaard, S., Arnould, E. J., \& Kjeldgaard, D. (2005). Postassimilationist ethnic consumer research: Qualifications and extensions. Journal of Consumer Research, 32(1), 160-170.

Askegaard, S., \& Ozcaglar-Toulouse, N. (2011). Still-crossing borders: migration, consumption and markets. Consumption, Markets and Culture, 14(3), 217-222.

Axelrod, M. (2001). Popular Culture and the Rituals of American Football. CLCWeb: Comparative Literature and Culture, 3(1).

Bandura, A. (1997). Self-efficacy: The exercise of control. New York: Freeman.

Batra, R., Ahuvia, A., \& Bagozzi, R. P. (2012). Brand Love. Journal of Marketing, 76(2), 1-16.

Belk, R., Price, L., \& Peñaloza, L. (2013). Consumer culture theory. Emerald Group, Bingley, UK.

Berry, J. W. (1980). Acculturation as varieties of adaptation, in A. M. Padilla (Ed.), Acculturation: Theory, 
models, and some new findings, Westview, Boulder, CO.

Berry, J. W. (1997). A critique of critical acculturation. International Journal of Intercultural Relations, 33(5), 361-371.

Berry, J. W. (2005). Acculturation: Living sucessfully in two cultures. International Journal of Intercultural Relations, 29(6), 697-712.

Berry, J. W. (2008). Globalisation and acculturation. International Journal of Intercultural Relations, 32(4), 328-336.

Bizumic, B. (2019). Effects of the dimensions of ethnocentrism on consumer ethnocentrism: An examination of multiple mediators. International Marketing Review, 36(5), 748-770.

Bourdieu, P. (1997). Sobre a televisão. Rio de Janeiro: Zahar.

Bourdieu, P. (2005). Esboço de auto-análise. São Paulo: Companhia das Letras.

Caliandro, A. (2014). Ethnography in digital spaces: Ethnogrpahy of virtual worlds, netnography, and digital ethnography, on: Denny, R. and Sunderland, P. (Eds)., Handbook of Anthropology in Business (pp. 658-680), Left Coast Press, Walnut Creek, CA.

Canclini, G. N. (1995). Hybrid Cultures: Strategies for Entering and Leaving Modernity. University of Minneapolis Press, Minneapolis, MN.

Chen, Z. T. (2018). Poetic prosumption of animation, comic, game and novel in a post-socialist China: A case of a popular video-sharing social media Bilibili as heterotopia. Journal of Consumer Culture. Avaliable from https://doi.org/10.1177/1469540518787574

Chernev, A., Hamilton, R., \& Gal, D. (2011). Competing for Consumer Identity: Limits to Self-Expression and the Perils of Lifestyle Branding. Journal of Marketing, 75(3), 66-82.

Clark, J. S., Apostolopoulou, A., \& Gladden, J. M. (2009). Real Women Watch Football: Gender Differences in the Consumption of the NFL Super Bowl Broadcast. Journal of Promotion Management, 15(1/2), 165-183.

Cleveland, M., \& Laroche, M. (2007). Acculturation to the global consumer culture: Scale development and research paradigm. Journal of Business Research, 60 (3), 249-259.

Colliander, J., \& Hauge Wien, A. (2013). Trash talk rebuffed: consumers' defense of companies criticized in online communities. European Journal of Marketing, 47(10), 1733-1757.

Cristofari, C., \& Guitton, M. J. (2017). Aca-fans and fan communities: An operative framework. Journal of Consumer Culture, 17(3), 713-731.

Cruz, A. G. B., \& Buchanan-Oliver, M. (2017). Moving toward settlement: tourism as acculturation practice. European Journal of Marketing, 51 (4), 772-794.

Davis, J. L., Fodor, A.; Pfahl, M. E., \& Stoner, J. (2014). Team interdependence and turnover: evidence from the NFL. American Journal of Business, 29(3/4), 276-292.

de Souza-Leão, A. L. M. S., \& Costa, F. Z. N. (2018). Agenciados pelo desejo: o consumo produtivo dos potterheads. RAE. Revista de Administração de Empresas, 58, 74-86.

de Souza-Leão, A. L. M., \& Moura, B. M. (2018). Temos que Pegar Todos! - Discursos Identitários sobre o Consumo de Pokémon GO no Brasil. Brazilian Journal of Marketing - BJM, 17(6), 895-913.

Dixon, A. W., Martinez, J. M., \& Martin, C. L. L. (2015). Employing social media as a marketing strategy in college sport: an examination of perceived effectiveness in accomplishing organizational objectives. International Review on Public and Nonprofit Marketing, 12, 97-113.

ESPN, (2017). ESPN quebra recorde histórico com transmissão exclusiva do Super Bowl na TV por assinatura. Available from http://www.espn.com.br/noticia/669285_espn-quebra-recorde-historicocom-transmissao-exclusiva-do-super-bowl-na-tv-por-assinatura

ESPN, (2018). Where every pro league should expand ... and where they will. Available from http://www.espn.com/nfl/story/_/id/24078578/where-nfl-nba-mlb-nhl-wnba-mls-nwsl-look-expansion

Felix, R., Rauschnabel, P. A., \& Hinsch, C. (2017). Elements of strategic social media marketing: A holistic framework. Journal of Business Research, 70, 118-126.

Fernandez Espinosa, D., \& Xiao, L. (2018). Twitter Users' Privacy Concerns: What do Their Accounts' First Names Tell Us? Journal of Data and Information Science, 3(1), 40-53.

Filo, K., Lock, D., \& Karg, A. (2015). Sport and social media research: A review. Sport Management Review, 18(2), 166-181.

Firmino, A. (2018). Conheça a história das transmissões do Super Bowl no Brasil. Available from: https://www.atribuna.com.br/2.713/conheça-a-história-das-transmissões-do-super-bowl-no-brasil- 


\subsection{7}

Francischini, G. (2018). Detentora dos direitos da NFL no Brasil, ESPN transmitirá mais de 140 partidas em nova temporada da Liga. Available from https://espnpressroom.com/brazil/press-releases/2018/09/detentora-dos-direitos-da-nfl-no-brasil-espn-transmitira-mais-de-140-partidasem-nova-temporada-da-liga/

Gentry, J., Jun, S., \& Tansuhaj, P. (1995). Consumer acculturation processes and cultural conflict: How generalizable in a North American model for marketing globally. Journal of Business Research, 32(2), 129-139.

Granot, E., Alejandro; T., \& Russel, L. (2014). A socio-marketing analysis of the concept of cute and its consumer culture implications. Journal of Consumer Culture, 14(1), 66-87.

Guschwan, M. (2012). Fandom, brandom and the limits of participatory culture. Journal of Consumer Culture, 12(1), 19-40.

Ha, J-P., Hums, M. A., \& Greenwell, C. T. (2014). The impact of acculturation and ethnic identity on American football identification and consumption among Asians in the United States. International Journal of Sports Marketing \& Sponsorship, 15(2), 47-64.

Hamilton, K., \& Alexander, M. (2017). Spatial, temporal and social dimensions of a "destination-in-motion". European Journal of Marketing, 51(11/12), 2101-2117.

Hills, M. (2013). Fiske's textual productivity and digital fandom: web 2.0 democratization versus fan distinction. Participations. Journal of Audience and Receptions Studies, 10 (1), 130-153.

Huang, R., Lee, S. H., Kim, H., \& Evans, L. (2015). The impact of brand experiences on brand resonance in multi-channel fashion retailing. Journal of Research in Interactive Marketing, 9(2), 129-147.

Izogo, E. E., \& Jayawardhena, C. (2018). Online shopping experience in an emerging e-retailing market. Journal of Research in Interactive Marketing, 12(2), 193-214.

Jamal, A. (2003). Marketing in a multicultural world: The interplay of marketing, ethnicity and consumption. European Journal of Marketing, 37(11/12), 1599-1620.

Jamal, A., Kizgin, H., Rana, N. P., Laroche, M., \& Dwivedi, Y. K. (2019). Impact of acculturation, online participation and involvement on voting intentions. Government Information Quarterly. Avaliable from https://doi.org/10.1016/j.giq.2019.04.001

Jenkins, H. (2006). Fans, Bloggers, and Gamers: Exploring Participatory Culture. NYU Press, New York, NY.

Jenkins, H. (2008). Convergence culture: Where old and new media collide. NYU Press, New York, NY.

Jenkins, H. (2014). Rethinking 'Rethinking Convergence/Culture'. Cultural Studies, 28(2), 267-297.

Jenkins, H., McPherson, T., \& Shattuc, J. (2002). Hop on Pop: The Politic and Pleasures of Popular Culture. Duke University Press, Durham, NC.

Juncklaus, L. R., Bini, T. J., \& Moretto Neto, L. (2016). Independência ou Norte: reflexões sobre a influência do estrangeirismo no campo do conhecimento da administração no Brasil. Cadernos EBAPE.BR, 14(1), 47-60.

Kiang, L., Glatz, T., \& Buchanan, C. M. (2016). Acculturation Conflict, Cultural Parenting Self-Efficacy, and Perceived Parenting Competence in Asian American and Latino/a Families. Family Process, 56(4), 943961.

Kizgin, H., Jamal, A., \& Richard, M.-O. (2018). Consumption of products from heritage and host cultures: The role of acculturation attitudes and behaviors. Journal of Business Research, 82(1), 320-329.

Kjeldgaard, D., \& Askegaard, S. (2006). The glocalization of youth culture: the global youth segment as structures of common difference. Journal of Consumer Research, 22(2), 231-247.

Kozinets, R.V. (2002). Can consumers escape the market? Emancipatory illuminations from burning man. Journal of Consumer Research, 29(1), 20-38.

Kozinets, R.V. (2010). Netnography: Doing Ethnographic Research Online. Sage, London, UK.

Kozinets, R.V. (2015). Netnography: Redefined. Sage, London, UK.

Langlois, G. (2013). Participatory Culture and the New Governance of Communication: The Paradox of Participatory Media. Television \& New Media, 14(2), 91-105.

Leão, G. (2018). Gol contra o soft power brasileiro. Revista Trama Interdisciplinar, 8(3).

Luedicke, M. K. (2011). Consumer acculturation theory: (crossing) conceptual boundaries. Consumption Markets and Culture, 14(3), 223-244.

Luedicke, M. K., Thompson, C. J., \& Giesler, M. (2010). Consumer Identity Work as Moral Protagonism: How Myth and Ideology Animate a Brand-Mediated Moral Conflict. Journal of Consumer Research, 
36(6), 1016-1032.

Ma, J., Yang, J., \& Yoo, B. (2020). The moderating role of personal cultural values on consumer ethnocentrism in developing countries: The case of Brazil and Russia. Journal of Business Research, 108, 375389.

Marques, L. K. S., \& Vidigal, F. (2018). Prosumers e redes sociais como fontes de informação mercadológica: uma análise sob a perspectiva da inteligência competitiva em empresas brasileiras. Transinformação, 30(1), 1-14.

Martin, D. (2012). Foreign women in Japanese television advertising: Content analyses of a cultural convergence paradigm. European Journal of Marketing, 46(1/2), 157-176

McAlexander, J. H.; Schouten, J. W., \& Koenig, H. F. (2002). Building Brand Community. Journal of Marketing, 66(1), 38-54.

Motta, F. C. P., Alcadipani, R., \& Bresler, R. (2001). Cultura Brasileira, Estrangeirismo e Segregação nas Organizações. Revista de Administração Contemporânea, 5(Special Edition), 59-79.

Mutch, A. (2003). Communities of Practice and Habitus: A Critique. Organization Studies, 24(3), 383401.

Næss, H. E. (2017). Authenticity matters: A digital ethnography of FIA World Rally Championship fan forums. Sport Management Review, 20(1), 105-113.

Nye Jr., J. S. (2015). Is the American Century Over?. Polity Press. Cambridge: UK.

Oates, T. P., \& Furness, Z. (Eds.) (2014). The NFL: Critical and Cultural Perspectives Temple University Press, Philadelphia, PA.

Ohata, E. (2020). Audiência do Super Bowl cresce 26\% na ESPN e bate recorde na TV paga. Avaliable from https://www.uol.com.br/esporte/ultimas-noticias/2020/02/06/audiencia-do-super-bowl-cresce26-na-espn-e-bate-recorde-na-tv-paga.htm

Ozanian, M. (2017). The Forbes Fab 40: The World's Most Valuable Sports Brands 2017. Available from: https://www.forbes.com/sites/mikeozanian/2017/10/24/the-forbes-fab-40-the-worlds-most-valuable-sports-brands-2017/\#628ecc693b84

Peñaloza, L. (1994). Atravesando fronteras/Border Crossings: A Critical Ethnographic Exploration of the Consumer Acculturation of Mexican Immigrants. Journal of Consumer Research, 21(1), 32-54.

Perdigão, A. P., Taborda, A. A., Pereira, C., Santos, M. C., \& Castagno Jr., R. L. (2016). Inteligência de marketing: utilizando a informação para compreender o mercado consumidor. Rev. FAE, 1 (Edição Especial), 61-75.

Ritzer, G. (2014). Prosumption: Evolution, revolution, or eternal return of the same? Journal of Consumer Culture, 14(1), 3-25.

Ritzer, G., \& Jurgenson, N. (2010). Production, Consumption, Prosumption: The nature of capitalism in the age of the digital 'prosumer'. Journal of Consumer Culture, 10(1), 13-36.

Rogenski, R. (2020). Super Bowl amplia conexão com fãs e marcas no Brasil. Available from https://www.meioemensagem.com.br/home/marketing/2020/01/29/super-bowl-amplia-conexaocom-fas-e-marcas-no-brasil.html

Samuel, A., Peattie, K., \& Doherty, B. (2018). Expanding the boundaries of brand communities: the case of Fairtrade Towns. European Journal of Marketing, 52(3/4), 758-782

Sandvoss, C. (2003). A Game of Two Halves: Football, Television, and Globalization. Routledge, New York, NY.

Sandvoss, C. (2005). Fans: The Mirror of Consumption. Polity Press, Cambridge, UK.

Santomier, J., \& Hogan, P. (2013). Social media and prosumerism: Implications for sport marketing research, in: S. Söderman, \& H. Dolles (Eds.), Handbook of research on sport and business (pp. 179-201). Edward Elgar, Cheltenham, UK.

Sawrikar, P., \& Muir, K. (2010). The myth of a 'fair go': Barriers to sport and recreational participation among Indian and other ethnic minority women in Australia. Sport Management Review, 13(4), 355367.

Segev, S., Ruvio, A., Shohan, A., \& Velan, D. (2014). Acculturation and consumer loyality among immigrants: a cross-national study. European Journal of Marketing, 48(9/10), 1579-1599.

Sharma, A., Kumar, V., \& Borah, S. B. (2017). Ritualization: A Strategic Tool to Position Brands in International Markets. Journal of Internationl Marketing, 25(2), 1-24.

Smith, R. A., \& Khawaja, N. G. (2011). A review of the acculturation experiences of international students. International Journal of Intercultural Relations, 35(6), 699-713. 
Sobol, K., Cleveland, M., \& Laroche, M. (2018). Globalization, national identity, biculturalism and consumer behavior: A longitudinal study of Dutch consumers. Journal of Business Research, 82(1), 340353.

Stavros, C., Meng, M. D., Westberg, K., \& Farrelly, F. (2014). Understanding fan motivation for interacting on social media. Sport Management Review, 17(4), 455-469.

Sugihartati, R. (2017). Youth fans of global popular culture: Between prosumer and free digital labourer. Journal of Consumer Culture. Avaliable from https://doi.org/10.1177\%2F1469540517736522

Tenconi, C. D., \& Cancellier, E. L. P. de L. (2016). Myreks - O Caso Da Startup Que Almeja O Mercado Mundial Dos Aplicativos. TPA - Teoria E Prática Em Administração, 6(1), 225-240.

Toffler, A., (1980). The Third Wave. William Morrow and Company, New York, NY.

Tombleson, B., \& Wolf, K. (2017). Rethinking the circuit of culture: How participatory culture has transformed cross-cultural communication. Public Relations Review, 43(1), 14-25.

Underberg, N. M., \& Zorn, E. (2013). Digital ethnography: anthropology, narrative, and new media. University of Texas Press, Austin, TX.

Ustuner, T., \& Holt, D. B. (2007). Dominated Consumer Acculturation: The Social Construction of Poor Migrant Women's Consumer Identity Projects in a Turkish Squatter. Journal of Consumer Research, 34(1), 4156

Veri, M. J., \& Liberti, R. (2013). Tailgate Warriors: Exploring Constructions of Masculinity, Food, and Football. Journal of Sport and Social Issues, 37(3), 227-244

Wallendorf, M., \& Arnould, E. (1991). "We Gather Together": Consumption Rituals of Thanksgiving Day. Journal of Consumer Research, 18(1), 18-31.

Weller, K., Bruns, A., Burgess, J., Mahrt, M., \& Puschmann, C. (Eds) (2014). Twitter and Society. New York: Peter Lang.

Wenger, E. (2001). Communities of practice: Learning, meaning and identity. Cambridge: Cambridge University Press.

Wenner, L. (2008). Super-Cooled Sports Dirt: Moral Contagion and Super Bowl Commercials in the Shadows of Janet Jackson. Television and New Media, 9(2), 131-154.

Wenner, L. (2012). Reflections on Communication and Sport: On Reading Sport and Narrative Ethics. Communication and Sport, 1(1/2), 188-199.

Wenner, L. (2014). Connecting events to advertising: Narrative strategies and dirty logics in Super Bowl commercials, in: K. Dashper, T. Fletcher and N. McCullogh (Eds). Sport Events, Society and Culture, Routledge, Abingdon, UK.

Whannel, G. (2014). The paradoxical character of live television sport in the twenty-first century. Television and New Media, 15(8), 769-776.

Willis, Z. (2020). Do People in Other Countries Watch the Super Bowl? Available from https://www.sportscasting.com/do-people-in-other-countries-watch-the-super-bowl/

Yoo, J. J. (2020). Does the Model Minority Image Work?: Consumer Responses to the Model Minority Stereotypes in Ads. Journal of Promotion Management, 1-31. Avaliable from https://doi.org/10.1080/10496491.2020.1745983

Zhang, J. (2009). The Effect of Advertising Appeals in Activating Self-Construals: A Case of Bicultural Chinese Generation X Consumers. Journal of Advertising, 38(1), 63-82.

Zimmer, M., \& Proferes, N. J. (2014). A topology of Twitter research: disciplines, methods, and ethics.

Aslib Journal of Information Management, 66(3), 250-261. 